\title{
Attitudes of Lebanese Secondary School Students and Teachers towards Biotechnology and its Teaching
}

\author{
H. Haidar ${ }^{1, *}$, M. Chouman ${ }^{1}$, P. Abou Tayeh ${ }^{1,2}$ \\ ${ }^{1}$ Doctoral School of Literature, Humanities and Social Sciences, Lebanese University, Dekweneh, Lebanon \\ ${ }^{2}$ Faculty of Pedagogy, Lebanese University, Beirut, Lebanon \\ *Corresponding author: hibahaidarr@gmail.com
}

Received April 11, 2014; Revised June 06, 2014; Accepted June 15, 2014

\begin{abstract}
Modern biotechnology has a large impact on society and requires informed decision-making and critical attitudes among the public. The purpose of this study was to determine the attitudes of Lebanese secondary school students and their biology teachers towards biotechnology and its teaching. Two questionnaires were administered to 400 students and 53 biology teachers. Results showed that teachers have more positive attitudes than students. Both had negative opinion towards consumption of genetically modified food. A mismatch between the teachers and their students was revealed concerning the socioconstructivist environment in biotechnology classes. The three components of attitudes (cognitive, affective and behavioral) were correlated in the case of students, while there was no correlation in the case of teachers.
\end{abstract}

Keywords: biotechnology, attitudes, secondary school, teachers, students, socioconstructivism

Cite This Article: H. Haidar, M. Chouman, and P. Abou Tayeh, "Attitudes of Lebanese Secondary School Students and Teachers towards Biotechnology and its Teaching." American Journal of Educational Research, vol. 2, no. 6 (2014): 430-435. doi: 10.12691/education-2-6-15.

\section{Introduction}

Biotechnology represents a complex domain where scientific, technological, social and ethical dimensions are interacting together. It includes a huge field of applications and opens new perspectives in environment, agriculture and health [1]. It is regarded as a very important development for both scientific and economic progress.

In fact, in many countries, some biotechnological applications are largely discussed for their economic and health effects (such as GMO and cloning). Consequently, people should be able to make informed and balanced decisions about scientific issues that concern their careers and daily lives which require a certain level of scientific literacy [2]. Being a scientifically literate person generally implies possessing a set of cognitive, affective and behavioral abilities needed to function effectively in an increasingly complex and technology dependent society. It also requires understanding the essence of competing arguments on a given controversy [3]. For this reason, governments and private sectors are strongly interested in supporting the concept of biotechnology education.

Therefore, the purpose of science education should be helping students to be able to participate in discussions about science, to question claims made by others about scientific matters, and to make informed decisions about the environment and their own health and well-being [4].

In this context appears the socioconstructivist approach which stresses the role of the interactions between students in the process of knowledge construction, mainly in the themes that have many domains such as biotechnology. In fact, this approach aims to enhance personal expression, creativity and development of autonomy in students. However, the approach that dominates in the teaching of scientific themes in many countries is still based on lecturing even if the teacher uses new technologies such as the internet [5].

Some researchers showed that there is a correlation between biotechnology knowledge and attitude $[6,7,8]$. In other words, as the person's knowledge increases, he has more positive attitude towards biotechnology. In contrast, other researchers refused this relationship $[9,10]$.

By examining these researchers, we noticed that most of them consider the attitude as a one-dimensional concept which is the evaluative feelings about a subject. This simple view of attitude could be a reason for the contradictory findings. Looking at these studies suggests that attitudes towards biotechnology do not yet constitute a coherent research area. Some studies defined attitudes in terms of benefits and risks, while others defined it in terms of acceptability or of general evaluation [2].

This seems to be a recurrent issue with research on attitudes. It is not only a complex construct, but a person's attitude seems also incomplete and in a state of evolution, especially in case of very complex subjects such as biotechnology [13].

However, the number of studies on attitudes towards biotechnology among the general public seems quite substantial, although many of them focused on students or teachers. In fact, studies that compare attitudes and interests of both teachers and students towards biotechnology applications and its teaching are scarce [12]. 
Concerning the interests of students towards biotechnology, results published by Eurobarometer [10] indicated that boys show less interest than girls towards some biotechnology applications such as GMF (Genetically Modified Food) and the use of human embryonic stem cells. Moreover, some researchers revealed that students have positive attitudes about the biotechnology applications whatever their interests were [14].

With respect to teachers, some researchers revealed that biology secondary teachers didn't have enough information about biotechnology items [12], and that their attitudes affect their intentions of teaching biotechnology subjects [4]. Other researchers showed that pre-service teachers disapproved the genetic modification of human and animal genes, and that their opinions were not influenced by course level enrolled in [9].

In Lebanon, modern biotechnology teaching has been introduced in the biology curriculum since 1998. In the secondary classes, the introduced concepts concern the techniques of genetic engineering such as transgenesis, genetic screening, cloning, production of high performance plants and production of hormones and antibodies. After the introduction of biotechnology in the educational program, it is necessary to investigate the interests and attitudes of students and teachers towards this subject and to explore their opinions about the biotechnology classroom environment.

The present study contributes to research on attitudes towards modern biotechnology by exploring the concept of attitudes in detail. We describe the concept of attitude based on the theoretical tripartite model of attitudes [2]. This model encompasses three basic attitude components: an affective, a cognitive and a behavioral component:

The affective component of attitudes reflects how persons feel about the subject.

The cognitive component is the evaluation of the subject using previous beliefs and knowledge.

The behavioral component is described as behavioral intentions.

The first objective of this study is to provide baseline data on the attitudes and interests of Lebanese students and biology teachers towards biotechnological topics and processes.

The second objective is to explore the opinions of students and teachers about the socioconstructivist environment of their biology classes.

\section{Materials and Methods}

Two questionnaires (Biotechnology Teaching Survey / Biotechnology Learning Survey - BTS/BLS) were given to 400 students, of $16-18$ years old, and to 53 teachers, from sixteen secondary schools scattered throughout Beirut and Mount Lebanon. These questionnaires measured the various attitude components in relation to knowledge content and different areas of modern biotechnology.

Results were coded and analyzed using SPSS (Statistical Package for the Social Sciences) software version 17.0. Student test (t-test) was performed to compare the mean responses of teachers and students. Bivariate correlation analysis was used to find the correlation between the different parameters.

\subsection{Participants}

Based on a list of Lebanese secondary schools in Beirut and Mount Lebanon, teachers were invited to participate with their students. A total of 25 schools were approached, of which sixteen consented to participate with one or more of their classes of 16-18 year old students and 53 of their biology teachers.

In Lebanon, the secondary education system for pupils aged between 15 and 18 years is divided into three main levels: Grade 10 (15-16 years), grade 11 (16-17 years), and grade 12 (17-18 years). A total sample size of 400 secondary school students (60\% girls and $40 \%$ boys) of grades 11 (43\%) and $12(57 \%)$ and 53 biology teachers (79\% women and $21 \%$ men) took part in the study.

\subsection{Design of Instruments}

The questionnaires were designed based on a variety of existing surveys of which items could be used for the purpose of the present study, including surveys on attitude towards science. The most important of these were the Eurobarometer [10], the BELBETS instruments of Kidman [12], the questionnaire of Mowen et al. [15], and the CLES instrument (Constructivist Learning Environment Survey) [16].

The first section of each instrument was designed to obtain demographic information about teachers and students. The other five sections of the instruments include five categories of items: cognitive evaluation (knowledge), interest, affective evaluation, behavioral intention, and class socioconstructivist environment items.

For the cognitive domain, in teachers' questionnaire, teachers provided a self-assessment of their knowledge levels using a four-point Likert-type scale $(1=$ no knowledge; 2 = little knowledge; 3 = some knowledge; or $4=$ knowledgeable). The 12 topics in this cognitive domain were: cloning, growth hormones, GMF, resistant plants, ethical biotechnology, environmental biotechnology, microbial biotechnology, recombinant DNA, transgenesis, human genome, bioremediation, and electrophoresis.

However, in students' questionnaire, issues in the cognitive domain were of two types:

- Four open questions about the definition of the following terms: biotechnology, cloning, GMF, and recombinant DNA.

- Five closed questions on the scale of Likert (2 = strongly agree, 1 = agree, 0 = neutral, $-1=$ disagree and -2 $=$ strongly disagree). They focused on genetically modified plants, genetically modified animals, DNA transfer and the use of GMO for medical reasons.

In the affective domain, 5 questions were designed to test the opinions of teachers and students in three areas: food, medical, and environmental applications. Thus, the topics considered were: the manipulation of plant genes in order to increase their nutritional values, the modification of genes of algae to produce biodiesel, the use of genetically modified animals to produce drugs, the use of human embryonic cells for therapeutic reasons and the modification of human genes to treat certain diseases.

In the behavioral domain, 5 questions were applied in teachers' questionnaire. They concerned the consumption of GMF by teachers or by their children, the consumption of medicine issued from GMO, the performance of genetic 
testing and the participation in protests against certain biotechnological applications. However, in students' questionnaire the two questions related to consumption of GMF by children and the genetic testing were absent.

With respect to the interest of teaching biotechnology, 7 questions were raised in teachers' questionnaire. Six issues concerning the teaching of the following themes: ethical, social and environmental features of biotechnology, human cloning and the aspects related to it, prenatal diagnosis, GMF and the interest to strengthen biotechnology knowledge. The seventh question was about the desire to increase knowledge in biotechnology. In students' questionnaire, the 2 questions related to prenatal diagnosis and the interest to strengthen the biotechnology knowledge were eliminated. The affective, behavioral and interests domains of the survey used a five point Likert scale (strongly agree, agree, neutral, disagree and strongly disagree).

In the socioconstructivist environment of biology class, 11 questions concerning 6 items were used: learning about the world, learning about the nature of science, learn to express in a courageous manner, learning how to learn, learning to communicate and interest of learning science. The responses were on 5 Likert scale: $(-2=$ never; $-1=$ seldom; 0 = sometimes; 1 = often; or 2 = always).

Student and teacher surveys might vary slightly. In some items, the statements differ in that a student may read a question written in the following way: "I learn how science can be part of the real life", whereas a teacher would read the same question as: "I explain to my students how science can be part of the real life”.

\subsection{Validity of Questionnaires}

Two pilot questionnaires were prepared, then they were examined by 2 professors in biotechnology and science education. The questions were reviewed and corrected. Thus, five questions were eliminated for BTS and seven for BLS. As a result, a total of 40 questions were present in the teachers' questionnaire and 33 questions in the students' one (without the personal profile questions).

Finally, pilot questionnaires were distributed to three biology teachers and 20 students from second secondary classes to seek information on the wording and readability of items. After analyzing the responses, a final correction was made.

\subsection{Reliability of Questionnaires}

Reliability is a measure of the internal consistency of questions. It is assessed by Cronbach alpha coefficient [17]. Table 1 reports the statistical data relevant to the internal consistency reliability.

Table 1. $\alpha$ Cronbach of the Questionnaires

\begin{tabular}{|c|c|c|c|} 
Table 1. $\alpha$ Cronbach of the Questionnaires \\
\begin{tabular}{|c|c|c|c|}
\hline Domain & $\begin{array}{c}\text { Number of } \\
\text { items }\end{array}$ & Participant & $\begin{array}{c}\text { Alpha } \\
\text { Cronbach }\end{array}$ \\
\hline Cognitive & 12 & Teachers & 0.908 \\
& 5 & Students & 0.585 \\
\hline Interest, affective and & 17 & Teachers & 0.824 \\
behavioral & 13 & Students & 0.638 \\
\hline Socioconstructivist & 11 & Teachers & 0.787 \\
environment & 11 & Students & 0.600 \\
\hline
\end{tabular}
\end{tabular}

In general, this ratio varies between 0 and 1 . The internal consistency of the questions is greater when the coefficient is closer to 1 [17]. Results show a high internal consistency for the teachers' questionnaire ( $\alpha$ varies between 0.787 and 0.908$)$ and an acceptable level for the students' questionnaire ( $\alpha$ varies between 0.585 and 0.638 ).

\section{Results}

\subsection{Interest to Biotechnology Education}

Statistical analysis (Table 2) showed a significant difference $(p<0.05)$ between students and teachers with respect to the introduction of topics related to bioethics education (2.3) and GMF (2.4) in the biology program of secondary classes. There is also a significant difference in the motivation towards strengthening their knowledge in biotechnology (2.5).

Table 2. Results of Means and t-Test for the Interest of Biotechnology Instruction

\begin{tabular}{|c|c|c|c|}
\hline \multirow{2}{*}{ Statements } & \multicolumn{2}{|c|}{ Mean } & \multirow{2}{*}{ t-test } \\
\hline & Teachers & Students & \\
\hline $\begin{array}{l}\text { 2.1-Subjects related to social } \\
\text { and environmental aspects of } \\
\text { biotechnology should be } \\
\text { added to the program in } \\
\text { secondary classes }\end{array}$ & 1.33 & 1.05 & 1.742 \\
\hline $\begin{array}{l}\text { 2.2-Human cloning and the } \\
\text { issues associated with it } \\
\text { should be discussed in } \\
\text { biotechnology lessons }\end{array}$ & 1.19 & 0.97 & 1.880 \\
\hline $\begin{array}{c}\text { 2.3-Bioethics education } \\
\text { should be discussed in } \\
\text { science lessons }\end{array}$ & 1.08 & 0.72 & $2.150^{*}$ \\
\hline $\begin{array}{c}\text { 2.4-Genetically modified } \\
\text { food should be integrated in } \\
\text { the program of } \\
\text { biotechnology }\end{array}$ & 1.37 & 0.75 & $5.270 * * *$ \\
\hline $\begin{array}{l}\text { 2.5-I like to strengthen my } \\
\text { knowledge and competencies } \\
\text { related to biotechnology } \\
\text { teaching }\end{array}$ & 1.52 & 1.03 & $4.086^{* * *}$ \\
\hline
\end{tabular}

In fact, teachers showed a more positive opinion than students for the presentation of bioethical issues and GMF and for the motivation to improve their biotechnology knowledge.

Both teachers and students showed positive views (with no significant difference) with respect to the introduction of social and environmental aspects of biotechnology as well as human cloning (2.1 and 2.2).

In summary, biology teachers had a more positive opinion than students to introduce topics related to biotechnology in the secondary classes' curriculum.

\subsection{Affective Domain}

Our results revealed that both students' and teachers' opinions are positive for the questions related to biotechnology applications (Table 3). However, the views of teachers were significantly more positive than students on the modification of algae genes to produce biodiesel (3.2), those of animals for the production of drugs (3.3), and on the use of human embryonic stem cells to cure certain diseases (3.4).

In summary, the positive perception among teachers was as follows, in decreasing order: Alter animal genes to produce drugs (3.3), use of embryonic cells (3.2), modify algae genes (3.4), alter human genes to treat genetic diseases (3.5) and change plants genes (3.1). 
This perception decreased in students and was located in a different decreasing order: Manipulation of plant genes (3.1), modification of human genes (3.5), use of embryonic cells (3.2), modifying algae genes to produce biodiesel (3.4) and altering of animal genes to produce drugs (3.3).

Table 3. Results of Means and t-Test for the Affective Domain

\begin{tabular}{|c|c|c|c|}
\hline Statements & \multicolumn{2}{|c|}{ Mean } & \multirow{2}{*}{ t-test } \\
\cline { 2 - 3 } & Teachers & Students & \\
\hline $\begin{array}{c}\text { 3.1-Alter plants genes to increase } \\
\text { their nutritional values }\end{array}$ & 0.83 & 0.81 & 0.103 \\
\hline $\begin{array}{c}\text { 3.2- Modify algae genes to produce } \\
\text { biodiesel }\end{array}$ & 1.21 & 0.58 & $4.445^{* * *}$ \\
\hline $\begin{array}{c}\text { 3.3- Use genetically modified } \\
\text { animals to produce medicines }\end{array}$ & 1.38 & 0.49 & $5.759 * * *$ \\
\hline $\begin{array}{c}\text { 3.4- Use genes of human embryonic } \\
\text { cells to treat certain diseases }\end{array}$ & 1.15 & 0.56 & $2.804^{* *}$ \\
\hline $\begin{array}{c}3.5-\text { Modify human genes to treat } \\
\text { genetic diseases }\end{array}$ & 0.92 & 0.67 & 1.107 \\
\hline$* *: \mathrm{p}<.01 ; * * *: \mathrm{p}<.001$ & & \\
\hline
\end{tabular}

\subsection{Behavioral Domain}

With respect to behavioral intentions, a significant difference between students and teachers in two topics has been observed (Table 4). Teachers were more tolerant than students concerning the intake of drugs from GMO (4.2), while students were more tolerant than teachers towards protesting against certain biotechnology applications (4.3).

For the consumption of GMF if they were cheaper (4.1), teachers and students showed negative views at this level.

Table 4. Results of Means and t-Test for the Behavioral Domain

\begin{tabular}{|c|c|c|c|}
\hline \multirow{2}{*}{ Statements } & \multicolumn{2}{|c|}{ Mean } & \multirow{2}{*}{ t-test } \\
\cline { 2 - 3 } & Teachers & Students & \multirow{2}{*}{0.537} \\
\hline $\begin{array}{c}\text { 4.1- I would eat genetically } \\
\text { modified food if it was } \\
\text { cheaper than normal food }\end{array}$ & -0.52 & -0.68 & $3.347^{* *}$ \\
\hline $\begin{array}{c}4.2-\text { I would take medicines } \\
\text { obtained from genetically } \\
\text { modified microorganisms }\end{array}$ & 0.87 & 0.22 & $-2.447^{*}$ \\
\hline $\begin{array}{c}4.3-\text { I would get involved in } \\
\text { protests against certain } \\
\text { biotechnology applications }\end{array}$ & -0.31 & 0.18 & \\
\hline$*: \mathrm{p}<0$.05; $* *: \mathrm{p}<0.01$ & & & \\
\hline
\end{tabular}

\subsection{Cognitive Domain in Teachers}

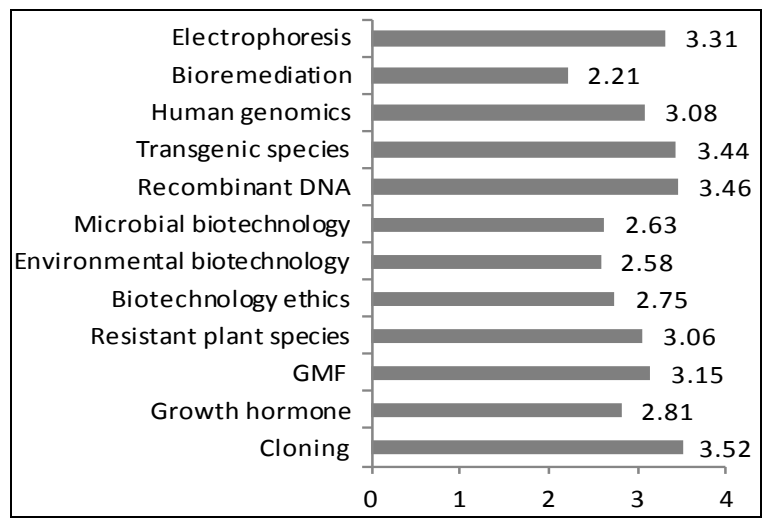

Figure 1. Means of responses concerning the cognitive domain in teachers

Analysis of the responses in Figure 1 showed that teachers considered their level of knowledge good for most items.
The classification of knowledge level in decreasing order was: cloning, recombinant DNA, transgenesis, electrophoresis, GMF, human genomics, resistant plants, growth hormones, bioethical, microbial biotechnology, environmental biotechnology and bioremediation.

\subsection{Cognitive Domain in Students}

Based on student responses to open and closed questions, we can consider that the students' knowledge about biotechnology themes were relatively low (Figure 2). These topics were classified in descending order according to the percentage of correct responses as follows: GMO, genetically modified plants and productivity, definition of biotechnology, genetically modified animals, DNA transfer, GMF, cloning, recombinant DNA.

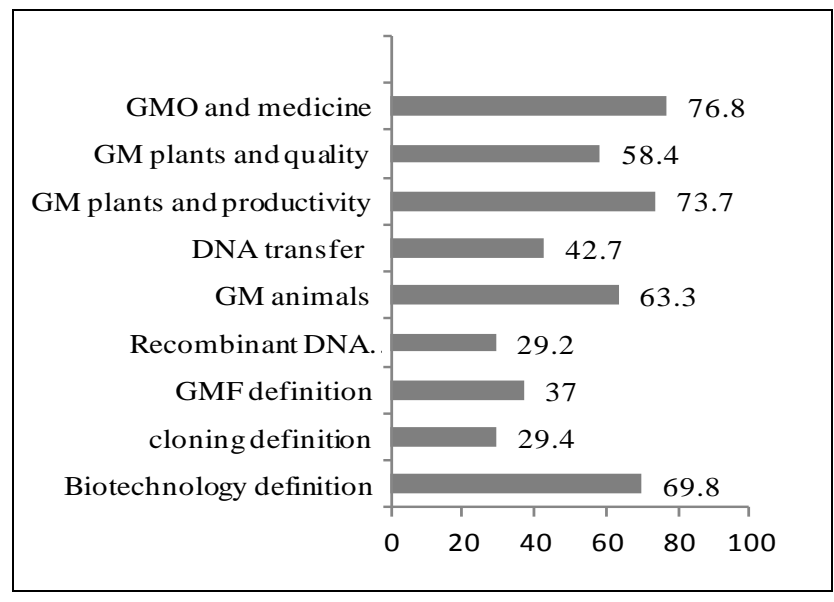

Figure 2. Percentage of correct responses of cognitive domain in students

\subsection{Socioconstructivist Environment in Class}

This part of the questionnaire aimed to assess if the environment of biotechnology class is considered as socioconstructivist. Table 5 shows a significant difference between the opinions of teachers and students in three characteristics out of six of the socioconstructivist approach applied in class.

Concerning learning about the world (5.2), most teachers indicated that their teaching of science started with problems related to real life, whereas only half of the students agreed to this statement.

With respect to the development of social behavior in students by helping them to express bravely in class (5.5 and 5.6), a notable difference between the responses of students and those of teachers was observed at this level. In fact, we can consider that there was a contradiction between the two types of responses. Indeed, $80.7 \%$ of teachers felt that they accept that their students ask "what is the importance of learning about it?" and only $30 \%$ of students believed that their teachers accepted. Similarly, $67.3 \%$ of teachers said they accept that students ask about the teaching method (5.6), while $22.4 \%$ only of students agreed that this was allowed in the classroom. Questions 5.7 and 5.8 emphasized on aspects that are rarely applicable and that are related to help students manage their own learning. A minority of teachers (28.9\%) and students $(27.1 \%)$ indicated that students participate in deciding the time required to perform an activity (5.7). On the choice of the activity (or project) that students will 
make (5.8), $22.9 \%$ of students indicated that this was applicable in their classrooms compared to $36.5 \%$ for teachers.

Table 5. Means and t-Test Concerning the Socioconstructivist Environment in Class

\begin{tabular}{|c|c|c|c|}
\hline \multirow{2}{*}{ Statement } & \multicolumn{2}{|c|}{ Mean } & \multirow{2}{*}{$\mathrm{t}$} \\
\hline & Teachers & Students & \\
\hline $\begin{array}{l}\text { 5.1-I explain to my students } \\
\text { how science can be part of } \\
\text { real life. }\end{array}$ & 1.62 & 1.37 & 1.743 \\
\hline $\begin{array}{l}\text { 5.2-My lessons start with } \\
\text { problems about real life. }\end{array}$ & 1.35 & 0.54 & $5.563^{* * *}$ \\
\hline $\begin{array}{l}\text { 5.3-I teach that science has } \\
\text { changed over time. }\end{array}$ & 0.87 & 0.77 & 0.564 \\
\hline $\begin{array}{l}\text { 5.4- I teach that science is } \\
\text { influenced by people's values } \\
\text { and opinions. }\end{array}$ & 0.02 & -0.23 & 1.543 \\
\hline $\begin{array}{l}\text { 5.5-I accept that a student asks } \\
\text { me "why do we have to learn } \\
\text { this item?" }\end{array}$ & 1.31 & -0.36 & $11.116^{* * *}$ \\
\hline $\begin{array}{l}\text { 5.6-I accept that a student asks } \\
\text { about the way he’s being } \\
\text { taught. }\end{array}$ & 0.96 & -0.61 & $9.052 * * *$ \\
\hline $\begin{array}{l}\text { 5.7-My students participate in } \\
\text { deciding how much time they } \\
\text { spend on activities. }\end{array}$ & -0.15 & -0.41 & 0.977 \\
\hline $\begin{array}{l}\text { 5.8- My students participate in } \\
\text { deciding which activity (or } \\
\text { project) they will do. }\end{array}$ & 0.15 & -0.65 & $4.239 * * *$ \\
\hline $\begin{array}{c}\text { 5.9- My students discuss } \\
\text { together about how to solve a } \\
\text { certain problem. }\end{array}$ & 0.73 & 0.54 & 0.903 \\
\hline $\begin{array}{l}5.10-\text { My students explain } \\
\text { their ideas to their colleagues. }\end{array}$ & 0.58 & 0.54 & -0.019 \\
\hline $\begin{array}{l}\text { 5.11-My students are } \\
\text { interested in science (or } \\
\text { biotechnology) lessons. }\end{array}$ & 0.94 & 0.85 & 1.113 \\
\hline
\end{tabular}

\subsection{Correlation between the Domains}

\subsubsection{Correlation in Teachers}

Bivariate analysis showed significant correlations between the affective and behavioral domains for teachers, while no correlation was found between these two domains and the cognitive one (Table 6). A correlation was also found between the interest in teaching biotechnology topics and each of the cognitive and affective domains.

Furthermore, no correlation was found between training sessions in biotechnology, years of experience, gender of the teacher and the different areas studied.

Table 6. Correlation Between the Different Parameters in Teachers

\begin{tabular}{|c|c|c|c|c|}
\hline \multirow{2}{*}{} & \multicolumn{4}{|c|}{ Correlation (Pearson r) } \\
\cline { 2 - 5 } & Cognitive & Affective & Behavioral & $\begin{array}{c}\text { Interest in } \\
\text { teaching }\end{array}$ \\
\hline Cognitive & 1 & 0.038 & 0.171 & $0.320^{*}$ \\
\hline Affective & 0.038 & 1 & $0.537^{* *}$ & $0.275^{*}$ \\
\hline behavioral & 0.171 & $0.537^{* *}$ & 1 & 0.222 \\
\hline $\begin{array}{c}\text { Interest in } \\
\text { teaching }\end{array}$ & $0.320^{*}$ & $0.275^{*}$ & .222 & 1 \\
\hline
\end{tabular}

\subsubsection{Correlation in Students}

The analysis of Table 7 show that cognitive, affective and behavioral domains were correlated with each others in students.

Moreover, gender of students was positively correlated with the desire to learn some topics in biotechnology and negatively correlated with the behavior related to biotechnology.
Table 7. Correlation Between the Different Parameters in Students

\begin{tabular}{|c|c|c|c|c|c|}
\hline & \multicolumn{5}{|c|}{ Correlation (Pearson r) } \\
\cline { 2 - 6 } & $\begin{array}{c}\text { Cognitiv } \\
\mathrm{e}\end{array}$ & $\begin{array}{c}\text { Affectiv } \\
\mathrm{e}\end{array}$ & $\begin{array}{c}\text { Behaviora } \\
\mathrm{l}\end{array}$ & $\begin{array}{c}\text { Interest } \\
\text { of } \\
\text { learnin } \\
\mathrm{g}\end{array}$ & Gender \\
\hline Cognitive & 1 & $.274^{* *}$ & $0.209^{* *}$ & 0.062 & -.039 \\
\hline Affective & $0.274^{* *}$ & 1 & $0.173^{* *}$ & $.194^{* *}$ & -.027 \\
\hline $\begin{array}{c}\text { Behaviora } \\
\text { l }\end{array}$ & $0.209^{* *}$ & $0.173^{* *}$ & 1 & -.093 & $-.132^{* *}$ \\
\hline $\begin{array}{c}\text { Interest of } \\
\text { learning }\end{array}$ & 0.062 & $0.194^{* *}$ & -.093 & 1 & $\begin{array}{c}0.204^{*} \\
*\end{array}$ \\
\hline Gender & -.039 & -.027 & $-.132^{* *}$ & $\begin{array}{c}0.204^{*} \\
*\end{array}$ & 1 \\
\hline
\end{tabular}

\section{Discussion}

By comparing the results of biology teachers with those of students in secondary classes, we found that teachers were more motivated than students to introduce the themes of human cloning and GMF in the program.

Similarly, at the therapeutic and environmental levels, teachers' responses were considerably more positive than those of students in the use of human embryonic cells and in genetic modifications of animals for the production of drugs and for the production of biodiesel from algae.

These results confirm those of other researches [10-20] carried out in the USA, Turkey, Slovenia and in several European countries concerning the attitudes of teachers or students. On the opposite, Kidman [12] showed that Australian teachers have a negative attitude towards the teaching of biotechnology, while their students have a positive attitude towards learning biotechnology and biotechnological applications.

A difference in the correlation between the 3 components of attitude for teachers and students was found: the affective and the behavioral components were related to the cognitive domain in the case of students while they were not correlated in the case of teachers.

This difference means that students' knowledge influence their emotions and behavior which is not the case for teachers. In fact, according to Klop and Severiens [2], the cognitive component (in which social representations are anchored) may have a dominant effect in some cases (as in the case of students in our study), whereas the affective component is the one that can have this dominant effect in other cases (for instance in teachers).

This difference between teachers and students could be explained by the fact that both affective and behavioral components of attitudes are in the route of formation in students, so they are not yet in a stable state.

These results show that the education of the scientific spirit in young people is easier because they are less influenced by their emotions. This requires the education of a curriculum that takes into account this purpose.

As regards to the socioconstructivist environment, we noticed that teachers felt they apply socioconstructivist dimensions in the classroom while this was not perceived by students. This indicates an inconsistency between practices declared by teachers and those actually carried out in the classroom.

These results indicate that teachers need to deepen the social constructivist concept in the process of education. Teacher training should also take into consideration this 
type of teaching and especially the importance of interactive debates in classroom.

In Lebanon, it is very rare for the curriculum to be written following consultation with teachers or students. Yet, data from this study indicates that it may be beneficial to determine the attitudes and interests of the students, as in some cases there will be disparities with the attitudes and interests of the teacher. These attitudes may differ, providing a rich discussion or debates in the classroom. Where attitudes tend to match, it is highly unlikely the match will be unanimous, so debate and discussion are still possible.

Results have also shown that students have very clear ideas of what they are interested in exploring in biology classes. Where these interests are not being met, it is possible that students will withdraw from studying biology.

\section{Conclusion}

This research aimed to investigate the relation which exists between the attitudes of Lebanese secondary school biology teachers and their students towards biotechnology and its teaching. Two questionnaires were distributed to 400 students and 53 biology teachers in 16 schools among Beirut City and Mount Lebanon. Results showed that teachers had more positive opinions than students for teaching biotechnology, for therapeutic use of human embryonic cells, and for the production of biodiesel from algae. A mismatch between the teachers and their students was found concerning the application of socioconstructivist approach in class.

Moreover, the opinions and the intentional behaviors of students were correlated to their knowledge, while no correlation was observed in teachers.

Although limitations have to be taken into account, the findings of this study highlight issues that may have to be considered by curriculum planners and science teachers who wish to incorporate scientific literacy into science curricula. When educating students about modern biotechnology and its implications, one has to keep in mind that students hold different starting points when considering modern biotechnology. Not only should science education focus on knowledge and understanding, but also on the affective side of biotechnology. This change in emphasis might help students to create a more balanced attitude towards biotechnology. These findings should be taken into account in the development of educational programs for secondary school students on informed decision-making towards modern biotechnology.

\section{Competing Interests}

The authors declare no competing interests.

\section{List of Abbreviations}

BLS: Biotechnology Learning Survey.

BTS: Biotechnology Teaching Survey.

BELBETS: Biotechnology Education Learning Biotechnology Education Teaching Surveys. CLES: Constructivist Learning Environment Survey.
GMF: Genetically Modified Food.

GMO: Genetically Modified Organism.

\section{References}

[1] France, B., Location: Positioning biotechnology education for the 21st century, Studies in Science Education, 43 (1), 88-122, 2007.

[2] Klop, T., Severiens, S., An exploration of attitudes towards modern biotechnology: A study among Dutch secondary school students, International Journal of Science Education, 29 (5), 663679, 2007.

[3] Moreland, J., and Jones, A., Developing Pedagogical Content Knowledge for the New Sciences: The example of biotechnology, Teaching Education, 17, 143-155, 2006.

[4] Fonseca, M. J., Costa, P., Lencastre, L., and Tavares, F., Disclosing biology teachers' beliefs about biotechnology and biotechnology education, Teaching and Teacher Education, 28(3), 368-381, 2012.

[5] Abd-El-Khalick, F., BouJaoude, S., Duschl, R. A., Hofstein, A., Lederman, N. G., Mamlok, R., Niaz, M., Treagust, D., and Tuan, H., Inquiry in Science Education: International Perspectives, Science Education, 88, 397-419, 2004

[6] Prokop, P., Prokop, M., and Tunicliffe, S.D., Is biology boring? Student attitudes toward biology, Journal of Biological Education, 42 (1), 36-39, 2007.

[7] Sorgo, A., and Ambrozic-Dolinsek, J., Knowledge of attitudes toward and acceptance of genetically modified organisms among prospective teachers of biology, home economics, and grade school in Slovenia, Biochemistry and Molecular Biology Education, 38 (3), 141-150, 2010.

[8] Massarani, L., and Moreira, I. C., Attitudes towards genetics: a case study among Brazilian high school students, Public Understanding of Science, 14, 201-212, 2005.

[9] Mweene Chabalengula, V., Mumba, F., and Chitiyo, J., American elementary education pre-service teachers' attitudes towards biotechnology processes, International Journal of Environmental \& Science Education, 6 (4), 341-357, 2011.

[10] Gaskell, G., Stares S., Allansdottir, A., Allum, N., Corchero, C., Fischler C., and Wagner, W., Europeans and biotechnology in 2005: Patterns and trends, Final report on Eurobarometer, Brussels: European Commission, Research Directorate-General, 2006.

[11] Dawson, V., An exploration of high school (12-17 year old) students' understandings of, and attitudes towards biotechnology processes, Research in Science Education, 37 (1), 59-73, 2007.

[12] Kidman, G., Attitudes and interests towards biotechnology: The mismatch between students and teachers, Eurasia Journal of Mathematics, Science and Technology, 5, 135-143, 2009.

[13] Ajzen, I., Nature and operation of attitudes, Annual Review of Psychology, 52, 27-58, 2001.

[14] Tuna, F., and Incekara S., An assessment of Turkish secondary school students' attitudes towards biotechnology in the perspective of genetically modified foods, Scientific Research and Essays, 6 (14), 3072-3078, July, 2011.

[15] Mowen, D., Roberts, T., and Wingenbach G., Biotechnology: An assessment of agricultural science teachers' knowledge and attitudes, Journal of Agricultural Education, 48 (1), 42-51, 2007.

[16] Taylor, C., Fraser, J., and Dawson, V., A constructivist perspective on monitoring classroom learning environments under transformation, Paper presented at the annual meeting of the American Educational Research Association, San Fransisco, 1995.

[17] George, D., and Mallery, P., SPPS for windows step by step: A simple guide and reference 14.0 update, Seventh edition, Pearson Education, Boston, 2007.

[18] Tegegne, F., Aziz, A., Bhavsar H., and Wiemer, R., Awareness of and attitudes towards biotechnology by Tennessee State University students with different backgrounds and majors, Journal of Biotech Research, 5,16-23, 2013.

[19] Darçin, E., Turkish pre-service science teachers' knowledge and attitude towards application areas of biotechnology, Scientific Research and Essays, 6 (5), 1013-1019, March 2011.

[20] Sorgo, A., Ambrozin-Dolinsek, J., Asak, M., and Ozel M., Knowledge about and acceptance of genetically modified organisms among pre-service teachers: A comparative study of Turkey and Slovenia, Electronic Journal of Biotechnology, 14 (4), 2011. [Accessed June 11, 2012]. 